Vol 11, Issue 11, 2018

\title{
DESCRIPTION OF TESTIS HISTOLOGY OF MUS MUSCULUS AFTER GIVING NANO HERBAL RHODOMYRTUS TOMENTOSA (HARAMONTING)
}

\author{
PUTRI CAHAYA SITUMORANG, SYAFRUDDIN ILYAS* \\ Department of Biology, Faculty of Mathematics and Natural Sciences, Universitas Sumatera Utara, Medan, 20155, Indonesia. \\ Email: syafruddin6@usu.ac.id
}

Received: 10 August 2018, Revised and Accepted: 24 September 2018

\section{ABSTARCT}

Objective: The objective of this study was to determine the description of testis histology of male mice (Mus musculus) after giving nano-Rhodomyrtus tomentosa (haramonting).

Methods: Leaves of $R$. tomentosa (haramonting) are made into nanoherbal using high-energy milling, treatment of mice in 14 days, then observation of testis histology, and the data processed with SPSS 22 program with Kruskal-Wallis test

Results: Nano- $R$. tomentosa administration was not significantly different in weight of testes ( $p>0.05)$, but there was significant difference in Spermatogonia, Spermatocytes, and spermatid.

Conclusions: Nano-R. tomentosa (haramonting) with excessive doses can cause damage of testis cells, interfere with the process of spermatogenesis, and make infertile.

Keywords: Nanotechnology, Nano herbal, Rhodomyrtus tomentosa, Spermatogonia, Spermatocytes, Spermatid.

(C) 2018 The Authors. Published by Innovare Academic Sciences Pvt Ltd. This is an open access article under the CC BY license (http://creativecommons. org/licenses/by/4. 0/) DOI: http://dx.doi.org/10.22159/ajpcr.2018.v11i11.29042

\section{INTRODUCTION}

Nanotechnology and study of nanoscale have grown rapidly over the past few years in large numbers with various product results. This provides opportunities for material development, i.e., for medical applications, where conventional techniques can reach their limits [1]. The marketed nano herbal products are Aegis, Lifepak Nano, Nano phyto proflex, Nano garcinia raspberry, Nano green coffee, Nano D3, Curcuma longa, Gymnema sylvestre, Salvia miltiorrhiza, proteins, and many more. Hence, nano herbal drugs have become the broad view of new nanotech era for better and safer health care [2]. Nanotechnology commonly refers to structures that are up to several $100 \mathrm{~nm}$ in size which can be increased up to $1000 \mathrm{~nm}$. Nanoscale materials have a particle size of a billionth of a meter [3]. The use of herbal medicines has been practiced for thousands of years ago and has a smaller effect compared to synthetic drugs. In addition, the presence of dietary supplements and nutraceuticals derived from plants also plays a role in improving herbs in the market [4]. Herbal remedies have hundreds of constituents that all work together to fight disease [5]. There are many nanoscale materials such as nanomaterials, nanoparticles, nano composers, nano energy, and nano herbs that are used as medicines. Therefore, the size of the drug given is smaller than the size of the cells of the human body, the drug ingredients are easy to the cell, and a better bioavailability reaction occurs, such as bacterial cells. The drug ingredients who have a smaller particle than size of bacterial cells, it will cause the drug ingredients to penetrate with easily, thus inhibiting of bacterial growth more quickly. [6].

Rhodomyrtus tomentosa is called haramonting in Indonesia, especially in North Sumatera. R. tomentosa (Aiton) Hassk. (Family Myrtaceae) is an ornamental, evergreen shrub and grows up to four meters tall. This plant species is native to Southern and Southeastern Asia [7]. A total of 19 phenolic compounds were tentatively characterized, including stilbenes and ellagitannins as major components, followed by anthocyanins, flavonols, and gallic acid. Piceatannol, a promising health-promoting stilbene component [8]. Studies on $R$. tomentosa mainly focused on the bioactive compounds from leaves and aerial parts because of their antibacterial, DNA damage prevention, and antioxidant activities [9]. Spermatogenesis disorders can be caused by internal factors (age, psychology, hormones, and genetics) or external factors (temperature, nutrition, trauma, environmental pollution, and X-ray radiation) [10]. $R$. tomentosa has antioxidant content which is thought to be important for the testes. Researchers often research $R$. tomentosa using methanol/ethanol extract and aqueous. However, studies using nano- $R$. tomentosa in the testes have never been done. Hence, in this study, we examined the effect of nano- $R$. tomentosa to testes.

\section{METHODS}

This research used the completely randomized design with 30 male mice (Mus musculus), age 12-18 weeks, and an average of weight of 20-25 g. Experimental animal handling is done ethically where the mice are kept in Animal House of Biological Laboratory in Faculty Mathematics and Natural Science, Universitas Sumatera Utara.

Leaves of $R$. tomentosa (haramonting) are made into nano herbal using high-energy milling for $2 \mathrm{~h}$. The treatment consisted of six groups comprising of five male mice, i.e., CMC $0.5 \%$ (control) and nano- $R$. tomentosa at a dosage of $100 \mathrm{mg} ; 141,42 \mathrm{mg} ; 200 \mathrm{mg}$; $282,82 \mathrm{mg} ; 400 \mathrm{mg} / 20 \mathrm{~g}$ bw in 14 days and then took the testes with the method of disclasio cervicalis. The dose from the calculation of acute toxicity test using the Thompson Weil formula. Making of testicular histology was used paraffin method and staining of HematoxylinEosin(HE). Mixture is observed with magnification $\times 400$. Observations were made by counting 20 cells randomly with five fields of view and then process of data with the SPSS 22 program (Kruskal Wallis test).

\section{RESULTS}

Nano- $R$. tomentosa administration was not significantly different in weight of testes ( $p>0.05$ ). Based on Fig. 1, there is almost no difference in testicles in each treatment. Weight of testes was highest in the control group and T3. Treatment of T1 with $\mathrm{T} 2$ has the same weight as well as at 
high doses (T4 and T5) so that it can be seen that the administration of nano-R. tomentosa (haramonting) in the weight of the testicles does not show any significant differences in each dose (Fig. 1).

Based on statistical data, it is known that there are significant differences in spermatogonia after giving of nano-R. tomentosa $(\mathrm{p}<0.05)$ except control with T1 and T1 with T2 (p>0.05). Control with T1, T1, and $\mathrm{T} 2$ shows that the number of spermatogonia is almost the same even though the data are different. The highest spermatogonia was in the control group, and the lowest was at the highest dose, T5 (Fig. 2)

Nano- $R$. tomentosa administration was significantly different in spermatocytes after giving of nano- $R$. tomentosa $(\mathrm{p}<0.05)$ except $\mathrm{T} 1$ with T2 and T2 with T3 ( $>0.05)$. This is seen in Fig. 3 . T1 with T2 has almost the same amount as with $\mathrm{T} 2$ with $\mathrm{T} 3$, so it does not show a significant difference. The highest spermatocytes are in control (CMC $0.5 \%$ ) and the lowest are in T5.

Nano-R. tomentosa administration was significantly different in spermatid, after giving of nano- $R$. tomentosa $(\mathrm{p}<0.05)$ each treatment. There are differences in all treatment (control and treatment groups). The highest number of spermatids is at $0.5 \% \mathrm{CMC}$ (control) and the highest is at T5.

Administration of herbal nano- $R$. tomentosa (haramonting) with multilevel doses can cause damage. Based on the observations of dose level, the number of spermatogonia in each treatment was higher than the number of spermatocytes. The amount of spermatids is also higher than the amount of spermatocytes and spermatogonia (Fig. 4).

Based on histological observations, damage also occurred in the control $(0.5 \% \mathrm{CMC})$ but had the highest number of spermatids. Excessive doses can interfere with the process of spermatogenesis which is characterized by a decrease in the number of primary spermatocytes and spermatids. The testes were damaged in each dose increase and the

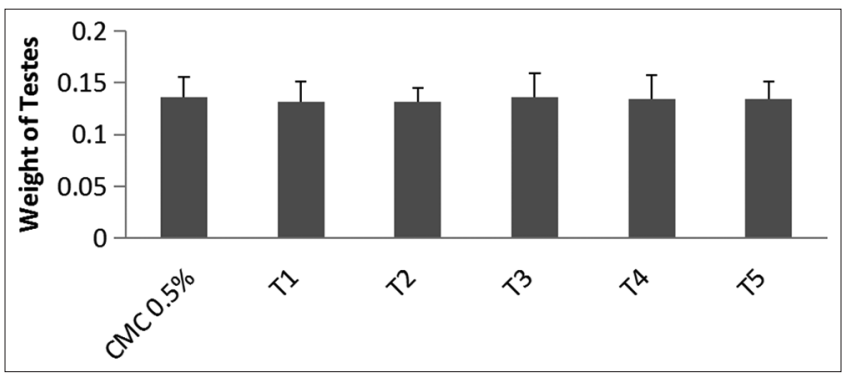

Fig. 1: Weight of testes after giving nano-Rhodomyrtus tomentosa $(\overline{\mathrm{X}} \pm \mathrm{SD})$

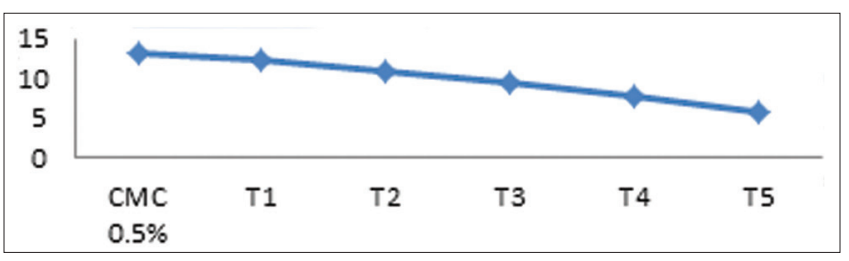

Fig. 2: Amount of spermatogonia after giving nano-Rhodomyrtus tomentosa (haramonting)

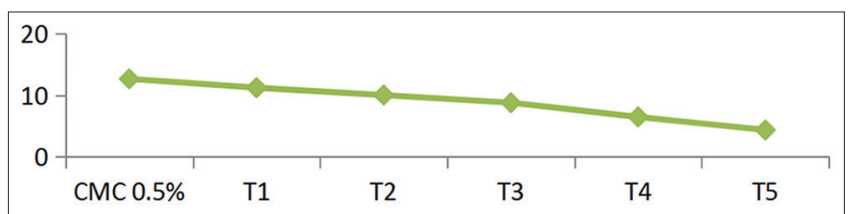

Fig. 3: Amount of spermatocytes after giving nano-Rhodomyrtus tomentosa (haramonting) greatest damage occurred at the highest dose found in T5 (Fig. 5). The lowest damage occurred in the control group. Tubular seminiferous has an unstructured shape, in contrast to control and T1 with T2. Heavy damage to the seminiferous tubules due to the highest dose is irreversible damage and can make infertile (Fig. 5).

\section{DISCUSSIONS}

R. tomentosa is a valuable herb that is worth additional attention because of its wide uses, extensive biological activities, and reliable clinical efficacy [11]. However, it does not affect the weight of the testes in mice. Every mice has different in immune systems, metabolic processes, appetite, and activities. The difference causes the testicular organs to have almost the same weight even though with different treatments. Even in the highest dose treatment, It did not affect to weight of testes. It depends on the body's response and the metabolism of the mice. Serum levels of testosterone, follicular-stimulating hormone, and luteinizing hormone ( $\mathrm{LH})$ and the levels of protein, ascorbic acid, glycogen, fructose, sperm motility, and sperm density were decreased significantly as compared to control group, and Fertility percentage was also decreased in treated groups [12]. Decreased of sperm due the content/dose of flavonoids in excess in $R$. tomentosa which acts as an antioxidant forms Reactive Oxygen Species (ROS). Antioxidants and ROS will both damage the cell membrane so that epididymal cells become damaged, and the metabolic process does not go as it should. Increased levels of ROS will result in oxidative stress, due to ROS levels exceeding the limits of the body's antioxidant defenses, so that it will cause damage to cells, tissues, and organs [13].

R. tomentosa contains the high of tannins. However, tannins in the diet can reduce protein digestibility of non-ruminants. Tannin-rich feed decrease the digestibility of proteins and dry matter due to the tannin inhibitory effect on trypsin and other digestive enzymes activity in the intestines of rat and chicken [14]. The histology of the testicular seminiferous tubules shows clearer and denser spermatogenic cells in the control group than in the treatment group. Male rat infertility and conditions of impaired spermatogenesis may involve different mechanisms of testicular damage. In the seminiferous tubules, it was possible to observe spermatogenic cell lines and Sertoli cells composing the seminiferous epithelium, plus tubular lumen, and tunica. Sertoli cells provide mechanical and nutritional support for developing germ cells [15].

Administration of nano- $R$. tomentosa can reduce the number of spermatogonia (Fig. 2). Tannins have biological activities such as can agglomerate proteins which interfere with the mechanism of energy release for motility, so spermatogonia are disrupted. Provision of active compounds in $R$. tomentosa can inhibit spermatogonia cell formation into spermatocytes; spermatids become spermatozoa experiencing obstacles. Therefore, there is a decrease in spermatogonia in microscopic observation with $\times 400$ magnification, presumably as a result of the presence of alkaloid and tannin secondary metabolites that

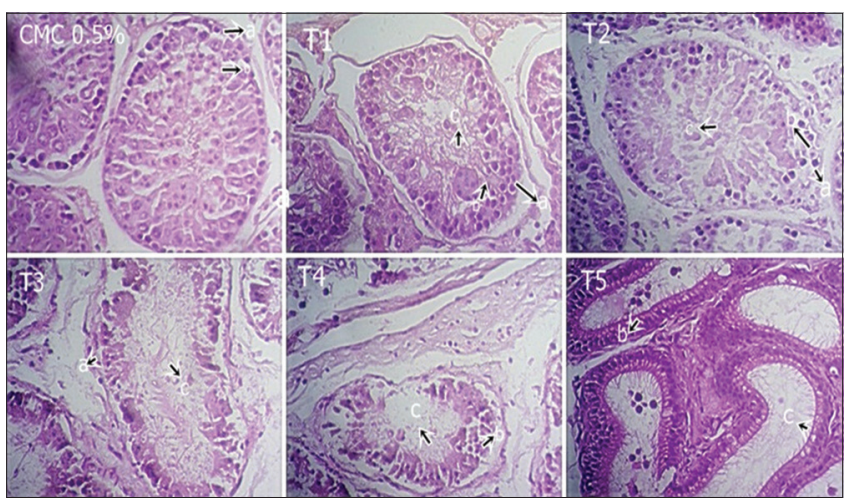

Fig.4 : Histology of testes after giving nano-Rhodomyrtus tomentosa (haramonting), (a) Spermatogonia, (b) Spermatocytes, (c) Spermatids $(\times 400)$ 


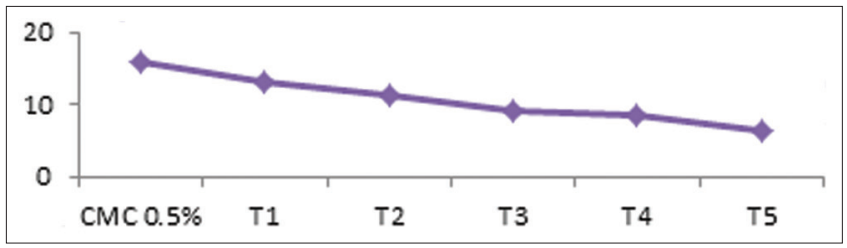

Fig. 5: Amount of spermatids after giving nano-Rhodomyrtus tomentosa (haramonting)

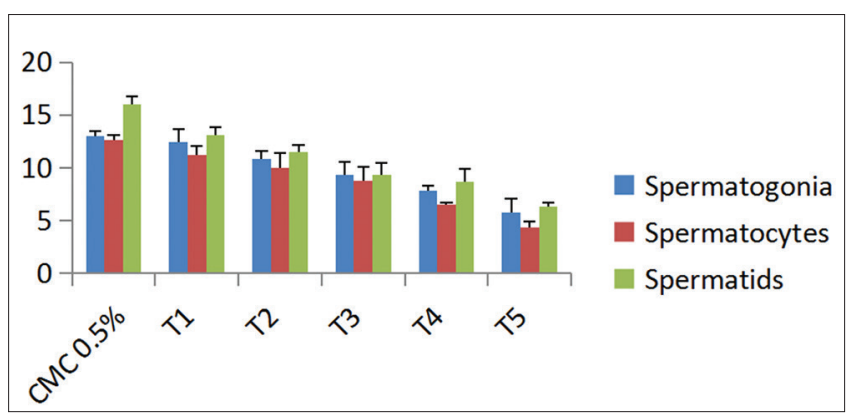

Fig. 6: Average of spermatogonia, spermatocytes, and spermatids for each treatment $(\bar{X} \pm S D)$

enter with the nanoscale.

Administration of nano- $R$. tomentosa can reduce the number of spermatocytes (Fig. 3). This decrease in the number of primary spermatocytes was supported also by Everitt's 1990 statement, and spermatocytes are very sensitive to external influences and tend to be damaged after the first meiotic prophase, especially at the pachytene stage, when the crossing occurs between homologous chromosomes [16]. When spermatocytes are damaged, Sertoli cells will degenerate and diffagocytose, so amount of spermatocytes are reduced. Decreased of spermatocytes can also decreased of spermatids in meiosis process in second stage. Barriers to one stage of spermatogenesis will affect the next stage [17].

Administration of nano- $R$. tomentosa can also reduce the number of spermatids (Fig. 6). The decrease in the number of spermatids is thought to be based on disruption of several mechanisms; one of them is Sertoli cells which have decreased, due to pyruvate and lactate deficiency which are the source of energy [18]. The number of spermatocytes is lower than spermatogonia (Fig. 4) because the disrupted process of spermatogonia becomes spermatocytes. The resulting spermatid cells are suspected to be abnormal. Based on the results of phytochemical screening, active substances that are thought to have antifertility effects are alkaloids [19].

Alkaloids are estrogenic whose working mechanism resembles natural estrogen, so it is able to bind to estrogen receptors. With the presence of alkaloid compounds, the level of free testosterone in blood plasma will increase and there will be a negative feedback mechanism that can inhibit the anterior pituitary to produce of LH. The decrease in LH levels can reduce testosterone production [20]. Decrease of intratesticular testosterone concentration was caspase- 3 activation dependent and increase in active caspase- 3 in the nucleus may be involved in the induction of decreased sperm production [21]. Giving hormones can cause low intratesticular testosterone so that it can induce Fas protein expression in germ cells [22]. Besides of necrosis cells due to this plant, apoptotic process in germ cell can also be triggered by exposing certain plant secondary metabolite to certain cells [23].

Clear damage can be compared in the histology of the control group with T5 (Fig. 5). The histological forms in T3 and T5 look unstructured. The process of spermatogenesis or stages of spermatozoa cell formation ranging from spermatogonia and spermatocytes and spermatids greatly was determined by the concentration of spermatozoa [24]. In addition to excessive tannin, ROS also causes DNA damage through apoptosis of germ cells [25]. The nature of the cause of ROS causes oxidative stress. Many free radicals can disrupt the cell structure from the cell membrane to the cell nucleus [26]. The causes and molecular mechanisms involved in germ cell and programmed cell death appear to be important to adjust germ cell numbers to that of the supporting Sertoli cells and ensure the quality control of the gametes produced. In addition to disruption of the process of spermatogenesis, excessive toxic compounds in the seminiferous tubules cause infertile [27]. Therefore, it was known that the use of this herb must be considered again in humans. Because toxicity in humans cannot be fully extrapolated from research animals [28].

\section{CONCLUSIONS}

Nano-R. tomentosa administration was significantly different from each treatment $(p<0.05)$, but there was not significantly different in weight of testes ( $\mathrm{p}>0.05$ ), and Giving nano- $R$. tomentosa (Haramonting) with excessive doses can cause damage of testis cells and interfere with the process of spermatogenesis.

\section{ACKNOWLEDGMENT}

Authors are grateful to the Directorate of Research and Community Service, Directorate General of Research and Development, Ministry of Research, Technology, and Higher Education have funded our research in accordance with community service funding agreement for budgeting year 2018 (Fund of the research postgraduate team I).

\section{AUTHORS' CONTRIBUTIONS}

Putri Cahaya Situmorang undertook the most part during of research and preparation of manuscript and Syafruddin Ilyas acted as corresponding author with responsibility to review the content and English grammar.

\section{CONFLICTS OF INTEREST}

The authors have declared no conflicts of interest.

\section{REFERENCES}

1. Ratnam DV, Ankola DD, Bhardwaj V, Sahana DK, Kumar MN. Role of antioxidants in prophylaxis and therapy: A pharmaceutical perspective. J Control Release 2006;113:189-207.

2. Rajeshwar V, Shubham B, Jyoti G. Broad view of nano herbal medicine. Int J Rec Adv Sci Tech 2018;5:1-5.

3. Haskel R. Nanotechnology in Drug Discovery and Developmeny. Bristol: Myers Squibb; 2009. p. 1-8.

4. Thapa RK, Gulam MK, Kalpana PB, Parbati T. Herbal medicine incorporated nanoparticles: Advancements in herbal treatment. Asian J Biomed Pharm Sci 2013; 14:7-14.

5. Yadav D, Anis AC, Hemant K, Veena G, Mohd A, Suruchi S, et al. Novel approach: Herbal remedies and natural products in pharmaceutical science as nano drug delivery systems. Int J Pharm Tech 2011;3:3092-116.

6. Vijaykumar N, Venkateswarlu V, Raviraj P. Development of oral tablet dosage from incorporating drug nanoparticles. Res J Pharm Biochem sci 2010;1:952-5.

7. Winotai A, Tony W, Jhon AG. Herbivores in Thailand on Rhodomyrtus tomentosa (Myrtaceae), an invasive weed in Florida. Flor Ento 2005;88:104-5.

8. Lai TN, Herent MF, Quetin-Leclercq J, Nguyen TB, Rogez H, Larondelle Y, et al. Piceatannol, a potent bioactive stilbene, as major phenolic component in Rhodomyrtus tomentosa. Food Chem 2013;138:1421-30

9. Limsuwan S, Trip EN, Kouwen TR, Piersma S, Hiranrat A, Mahabusarakam W, et al. Rhodomyrtone: A new candidate as natural antibacterial drug from Rhodomyrtus tomentosa. Phytomedicine 2009;16:645-51.

10. Huhtaniemi IT. Endocrine Regulation of Male Reproduction. Finland: University of Turky; 2009. 
11. Hazrulrizawati AH, Senait SZ, Mashitah MY. Rhodomyrtus tomentosa: A phytochemical and pharmacological review. Asian J Pharm Clin Res 2017;10:10-6

12. Gupta KS. Antifertility activity of B-sitosterol isolated from Barleria prionitis (L.) roots in male albino rats. Int $\mathrm{J}$ Pharm Pharm Sci 2016;8:88-96.

13. Sikka SC. Relative impact of oxidative stress on male reproductive function. Curr Med Chem 2001;8:851-62.

14. Loss J. Tannins from different foodstuffs as trypsin inhibitors. Podsedek Pol J Food Nutr Sc 2004;13:51.

15. Hirai T, Tsujimura A, Ueda T, Fujita K, Matsuoka Y, Takao T, et al. Effect of 1,25-dihydroxyvitamin $\mathrm{d}$ on testicular morphology and gene expression in experimental cryptorchid mouse: Testis specific cDNA microarray analysis and potential implication in male infertility. J Urol 2009;181:1487-92.

16. Everitt B. Essential Reproduction. Oxford London Edinburg: Blackwell SCIENCE Publications; 1990.

17. Tajudin M. Cara Keluarga Berencana Untuk Pria. Dalam: Symposium Proses Reproduksi, Kesuburan dan Seks Pria dalam Perkawinan. Jakarta: Kedokteran Universitas Indonesia; 1986.

18. Grootegoed JA, Jansen R, Van der Molen HJ. The role of glucose, pyruvate and lactate in ATP production by rat spermatocytes and spermatids. Biochim Biophys Acta 1984;767:248-56.

19. Yakubu MT. Effect of a 60-day oral gavage of a crude alkaloid extract from Chromolaena odorata leaves on hormonal and spermatogenic indices of male rats. J Androl 2012;33:1199-207.

20. Chattopadhyay S, Chattopadhyay U, Mathur PP, Saini KS, Ghosal S. Effects of hippadine, an Amaryllidaceae alkaloid, on testicular function in rats. Planta Med 1983;49:252-4.

21. Nukman M, Asmarinah A, Nurjati CS, Syafruddin I. Testosterone undecanoate and depo medroxyprogesterone acetate induced azoospermia through increased expression of spermatogenic cell caspase 3. Med J Indo 2008; 17:149-56.

22. Ilyas S. Analysis of protein fas expression and caspase 3 activated at the supression phase to sperm quantity by androgen/progestin combination. J Biol Sumatera 2007;2:45-7.

23. Situmorang PC, Ilyas S. Review: Germinal cell apoptosis by herbal medicine. Asian J Pharm Clin Res 2018;9:24-31.

24. Ilyas S, Salomo H, Nursal. Quantity and quality of guinea pig (Cavia porcellus) spermatozoa after administration of methanol extract of bitter melon (Momordica charantia) seed and depot medroxy progesterone acetate (DMPA). Earth Environ Sci. 2018;130:12047.

25. Maneesh M, Jayalekshmi H, Dutta S, Chakrabarti A, Vasudevan DM. Role of oxidative stress in ethanol induced germ cell apoptosis - An experimental study in rats. Indian J Clin Biochem 2005;20:62-7.

26. Thomson PN, Delfi L, Arsyad KH, Syafruddin I. Influence of chitosan from shrimp skin to quality and quantity of sperm of albino rats after administration of lead. Andrology 2014;3:1

27. Ilyas S, Lestari SW, Moeloek N, Asmarinah, Siregar NC. Induction of rat germ cell apoptosis by testosterone undecanoate and depot medroxyprogesterone acetate and correlation of apoptotic cells with sperm concentration. Acta Med Indones 2013;45:32-7.

28. Fajriaty I, Ketut AF. Acute and sub-chronic (28 Days) repeated oral toxicity test of ethanol extract of lerak (Sapindus Rarak. Dc) Fruits in wistar rats. Int J Pharm Pharm Sci 2014;6:487-549. 